\title{
STRATEGIA PRZEDSIĘBIORSTWA SPOŁECZNIE ODPOWIEDZIALNEGO NA PRZYKLADZIE POLSKICH SPÓŁEK GIEŁDOWYCH
}

Z a ry s tre ś c i: Celem niniejszego artykułu jest prezentacja praktyki polskich przedsiębiorstw notowanych na GPW w zakresie realizacji założeń koncepcji społecznej odpowiedzialności przedsiębiorstw. Dla zrealizowania powyższego celu artykuł podzielony został na trzy części, pierwsza prezentuje założenia koncepcji społecznej odpowiedzialność, druga zaś omawia wpływ tej koncepcji na budowę i wdrożenie strategii we współczesnych jednostkach. Następnie omówiono stan obecny wdrożenia koncepcji CSR w działania strategiczne polskich spółek giełdowych, głównie odnosząc się do spółek wchodzących w skład RESPECT Indeks. W artykule posłużono się studium literatury, analizą dokumentów wtórnych.

S ł o w a k 1 u c z o w e: strategia przedsiębiorstwa, społeczne odpowiedzialność przedsiębiorstw, Respect Index

K 1 a s y fik a cja JE L: L21

\section{WSTĘP}

Świadomość społeczeństwa o potrzebie ochrony środowiska naturalnego oraz respektowania praw człowiek wpływa na funkcjonowanie współczesnych podmiotów gospodarczych nieustannie rośnie. Dalszy rozwój przedsiębiorstw na rynku silnie uzależniony jest nie tylko od pomnażanego zysku, ale także od podejmowanych działań w zakresie ochrony przyrody oraz na rzecz społeczności lokalnej. Koncepcja rozwoju społeczno-gospodarczego oparta na

*Adres do korespondencji: Joanna Piłacik, Uniwersytet Łódzki, Wydział Zarządzania, Katedra Rachunkowości, ul. Jana Matejki 22/26, 90-237 Łódź, e-mail: joanna.pilacik@uni.lodz.pl. 
nieustannej konsumpcji dóbr i usług, wykorzystaniu zasobów naturalnych przy jednoczesnej degradacji środowiska, doprowadza do nieodwracalnych zniszczeń w ekosystemie. By uniknąć negatywnego wpływu na przyrodę i związaną z nim jakość życia człowieka, przy zrównoważonym rozwoju aspektów ekonomicznych na popularności zyskała koncepcja społecznej odpowiedzialności bizne$\mathrm{su}^{1}$ Społeczna odpowiedzialność przedsiębiorstw jest nurtem wyznaczającym kierunek zmian w strategicznym zarządzaniu organizacją, który zobowiązuje firmy do zrównoważonego rozwoju z jednoczesnym poszanowaniem zasad zarówno ekonomii i tradycyjnego rozumienia celu prowadzonej działalności, jak i ekologii oraz etyki (w odniesieniu do szeroko rozumianego otoczenia). Należy podkreślić, że koncepcja ta nie utożsamia społecznej odpowiedzialności z filantropią - jest to dobra praktyka biznesowa [Sachs, 2009, s. 38]. Przedsiębiorstwo chcące odnieść sukces rynkowy powinno działać odpowiedzialnie wobec wszystkich interesariuszy. Jednakże, wiedza dotycząca problematyki społecznej odpowiedzialności w Polsce jest tematem zyskującym na popularności, zarówno w środowisku praktyków jak i naukowców. Coraz więcej publikacji oraz badań potwierdza, iż dobrze wdrożona do strategii (lub w tez cały model biznesowy) przedsiębiorstwa koncepcja społecznej odpowiedzialności przynosi zarówno lepszy obraz wizerunkowy, jak i wymierne korzyści finansowe dla podmiotu.

Biorąc pod uwagę powyższe rozważania, sformułowano cel artykułu jako prezentacja praktyki polskich przedsiębiorstw notowanych na GPW w zakresie realizacji założeń koncepcji społecznej odpowiedzialności przedsiębiorstw. Dla zrealizowania powyższego celu artykuł podzielony został na trzy części, pierwsza prezentuje założenia koncepcji społecznej odpowiedzialność, druga zaś omawia wpływ tej koncepcji na budowę i wdrożenie strategii we współczesnych jednostkach. Następnie omówiono stan obecny wdrożenia koncepcji CSR w działania strategiczne polskich spółek giełdowych, głównie odnosząc się do spółek wchodzących w skład RESPECT Indeks.

\section{IDEA SPOŁECZNEJ ODPOWIEDZIALNOŚCI PRZEDSIĘBIORSTW}

W literaturze przedmiotu brakuje jednomyślnej definicji CSR. Społeczna odpowiedzialność biznesu (CSR) jest przede wszystkim koncepcją, według której firmy dobrowolnie prowadzą działalność uwzględniającą interesy społeczne i

\footnotetext{
${ }^{1} \mathrm{~W}$ dalszej części artykułu pojęcie: „społeczna odpowiedzialność biznesu” używane jest zamiennie ze „społeczną odpowiedzialnością przedsiębiorstw” oraz skrótem CSR (Corporate Social Responsibility).
} 
ochronę środowiska, a także relacje z interesariuszami (czyli grupami lub jednostkami, które są wstanie wpływać lub są pod wpływem działania przedsiębiorstwa za pośrednictwem jego produktów, strategii i procesów). Odpowiedzialne społecznie przedsiębiorstwo nie tylko spełnia wszystkie wymagania formalne, ale także dobrowolnie angażuje się inwestując w zasoby ludzkie, ochronę środowiska i relacje z interesariuszami [Roszkowska, 2011, s.41-44]. Odpowiedzialny biznes to osiąganie trwałego zysku przy jednoczesnym, mądrym kształtowaniu relacji z otoczeniem, to potężne narzędzie zarządzania, to także poczucie odpowiedzialności za konsumenta, inwestora, społeczeństwo, środowisko naturalne, za sukces gospodarczy, stosowanie przejrzystych praktyk biznesowych opartych na poszanowaniu i szacunku dla pracowników, społeczności i środowiska [Gierusz, Martyniuk, 2009, s.128].

Profesor M. Porter, amerykański ekonomista, ekspert w dziedzinie strategii organizacji i konkurencji, stwierdził, że CSR to polityka i praktyki wzmacniające konkurencyjność przedsiębiorstwa, które równocześnie poprawiają warunki ekonomiczne i socjalne w społecznościach, w których organizacja prowadzi działalność. Dla potwierdzenia powyższego stwierdzenia, od kilku lat praktycy i teoretycy próbują odpowiedzieć na pytanie, czy wdrożenie założeń CSR do strategii podmiotu gospodarczego daje wymierne korzyści dla jednostki. Według badania z 2012 roku zleconego ${ }^{2}$ przez Polska Agencja Rozwoju Przedsiębiorczości (PARP), korzyści z realizacji CSR dostrzega 60\% firm, bez względu na to czy realizują działania społecznie odpowiedzialne czy nie. Są to korzyści takie jak: poprawa wizerunku firmy, zwiększenie motywacji pracowników czy generowanie przychodów[PARP, 2012]. W innym badaniu wśród korzyści w podejmowaniu działań CSR, wskazywanych przez firmy, dominowały wizerunkowe, relacyjne i finansowe[Forbs, PwC, 2014]. W Polsce strategia CSR jest nadal tematem relatywnie nowym i nie do końca poznanym. Cieszy się rosnącym zainteresowaniem $\mathrm{z}$ jednej strony podmiotów związanych $\mathrm{z}$ biznesem oraz administracją państwową, a z drugiej społeczeństwa. Z przytoczonych badań PARP pojęcie „społeczna odpowiedzialność biznesu” zna zaledwie 1/3 przedstawicieli firm działających w Polsce, w tym $70 \%$ to firmy duże. Jednakże badanie MIT Sloan Management Review oraz BCG [2014] stanowi dobry prognostyk dla polskiego rynku, gdyż pokazało, iż 70\% firm uwzględniających zrównoważony rozwój w swoich planach biznesowych, robi to od sześciu lat, a $20 \%$ od dwóch lat. Z punktu widzenia przedsiębiorstw ta koncepcja staje się wyznacznikiem ładu korporacyjnego oraz priorytetem w budowaniu kompleksowej strategii rozwoju przedsiębiorstwa, co w dobie globalizacji nie powinno zostać zignorowane przez polskie przedsiębiorstwa [Grudzewski i inni, 2010, s.26].

\footnotetext{
${ }^{2}$ Badanie zrealizowane na zlecenie Polskiej Agencji Rozwoju Przedsiębiorczości przez konsorcjum SMG/KRC Poland Media oraz PwC Polska w okresie od września do grudnia 2011.
} 


\section{SPOŁECZNA ODPOWIEDZIALNOŚĆ JAKO ELEMENT STRATEGII PRZEDSIĘBIORSTWA}

Traktując koncepcję społecznej odpowiedzialności biznesu w sposób operacyjny i strategiczny, należy pamiętać o tym, iż powinna ona być wdrażana w sposób zaplanowany i celowy. Sprostanie temu zadaniu nie jest proste, gdyż trzeba uwzględnić kilka istotnych kwestii już na etapie konstrukcji samej strategii [ Żychlewicz, 2015, s. 283]

Przedsiębiorstwa mogą przejawiać społeczną odpowiedzialność wobec interesariuszy zewnętrznych, środowiska przyrodniczego oraz wobec ogólnego dobrobytu społecznego. Jak pisze Griffin R.W. [2004, s. 118], niektóre organizacje uznają swoją odpowiedzialność we wszystkich trzech dziedzinach i usilnie dążą do sprostowania swym obowiązkom w każdej z nich, podczas gdy niektóre kładą nacisk tylko na jedną lub dwie dziedziny. Każda organizacja ma różnorodnych interesariuszy zewnętrznych, którzy odczuwają skutki jej działania i są zainteresowane jej wynikami. Interesariusze zewnętrzni to jednostki, których bezpośrednio dotyczy zachowanie organizacji i które są materialnie zainteresowanie jej wynikami, m.in. klienci, pracownicy i inwestorzy. Przyjęcie społecznej odpowiedzialności do strategii przedsiębiorstwa ponosi za sobą wiele konsekwencji dla zarządzania organizacją. Kierownicy i menedżerowie musza znać całe otoczenie organizacji, a co z tym idzie także interesariuszy wewnętrznych i zewnętrznych. Konieczne jest by dopilnowali, aby kontakty z partnerami oraz współdziałanie ze środowiskiem i społeczeństwem odbywały się w atmosferze społecznej odpowiedzialności. Społeczna odpowiedzialność przedsiębiorstwa stanowi zatem podejście długofalowe, którego podstawą jest dialog w celu znalezienia rozwiązań korzystnych zarówno dla przedsiębiorstwa (wygenerowanie zysków, konkurencyjność na rynku lokalnym i/lub globalnym), jak również pracowników w nim zatrudnionych, lokalnej ludności, współpracowników, kooperantów, inwestorów, dostawców i innych interesariuszy. Wśród wewnętrznych interesariuszy każdego przedsiębiorstwa pracownicy zajmują priorytetowe miejsce, gdyż mają oni bowiem bezpośrednie możliwości oddziaływania na nie. Kompetencja i zaangażowanie pracowników wpływa na realizację założeń strategii przedsiębiorstwa.

Podejście do budowania strategii przedsiębiorstwa społecznie odpowiedzialnego zależy od określenie sposobów realizacji kontekstu CSR w działalności biznesowej danej organizacji. Wybranie priorytetowych obszarów CSR do zarządzania może odbywać się na trzech poziomach. Pierwszy poziom to CSR jako filantropia korporacyjna - działania głównie polegają na dzieleniu się pieniędzmi lub umiejętnościami, mająca niewielki wpływ strategiczny na organizację. Kolejny poziom wdrażania CSR to zarządzanie ryzykiem -oznacza dążenie 
do zbudowania wzajemnego zaufania i przejrzystości zarówno w relacjach z otoczeniem zewnętrznym, jak i środowiskiem wewnętrznym organizacji $\mathrm{w}$ celu osiągnięcia przewagi konkurencyjnej. Trzeci poziom ma fundamentalny wpływ na strategiczną i operacyjną działalność przedsiębiorstw, wprowadza zrównoważony model biznesowy oraz tworzy wartość firmy. Przyjęta strategia powinna być zintegrowana $z$ systemem zarządzania przedsiębiorstwem, co daje możliwość zarządzania w sposób efektywny ryzykiem we wszystkich obszarach CSR oraz w podstawowej działalności gospodarczej jednostki. Długoterminowe i harmonizowane do działalności biznesowej podejście do wdrażania CSR w jednostki staje się postawą długofalowego budowania wartości firmy.

Zastosowanie reguł odpowiedzialnego biznesu stało się najpierw popularne w krajach wysokorozwiniętych, gdzie konsumenci zaczęli się domagać nie tylko dobrych jakościowo usług i produktów, ale również tych, które są produkowane $\mathrm{z}$ zachowaniem troski o środowisko naturalne, przy poszanowaniu praw pracowników oraz zachowaniu standardów etycznych [Zuzek D., 2012,s. 200]. Społeczną odpowiedzialność biznesu zdecydowanie łatwiej zauważyć w dużych przedsiębiorstwach (w tym w koncernach międzynarodowych), które działania w zakresie CSR mają bezpośrednio wpisane w podstawową strategię. Takie firmy są również najbardziej świadome korzyści płynących z realizacji działań w zakresie społecznej odpowiedzialności biznesu. Duże przedsiębiorstwa i koncerny międzynarodowe częściej promują swoją działalność w zakresie CSR prowadząc kampanie informacyjne lub publikując okresowe raporty na ten temat [Śnieżek, Wiatr, 2014, s.402].

Na rynkach finansowych koncepcja społecznej odpowiedzialności przedsiębiorstw na dobre zagościła w postaci lawinowego wzrostu zainteresowania inwestowaniem $\mathrm{w}$ przedsiębiorstwa na podstawie nie tylko ich finansowych, ale i społecznych wyników, obejmujących m.in. ochronę środowiska, wyzysk siły roboczej czy testy na zwierzętach. W Polsce od 2009 roku istnieje indeks giełdowy zrzeszający liderów wśród spółek odpowiedzialnych społecznie - Respect Index.

\section{STRATEGIA PRZEDSIĘBIORSTW CSR NA PRZYKŁADZIE SPÓŁEK RESPECT INDEX}

Na głównych rynkach giełdowych na świcie już od kilku lat funkcjonują indeksy społecznej odpowiedzialności biznesu, przyciągając w ten sposób na rynek inwestorów i emitentów, zwiększając obroty giełdowe i podnosząc jakość rynku papierów wartościowych. Są w nich ujmowane akcje spółek uznawanych za dominujące w zakresie CSR, w tym także w zakresie ochrony 
środowiska [Wróblewska, 2015, s.247]. Pierwsze elementy strategii CSR oraz jej dynamiczny rozwój w Polsce można było zaobserwować na początku XXI wieku, było to skutkiem zwiększenia liczby międzynarodowych inwestorów. Wprowadzenie przez Giełdę Papierów Wartościowych w Warszawie nowego indeksu giełdowego RESPECT miało na celu wyłonienie spółek zarządzanych w sposób odpowiedzialny i zrównoważony, dodatkowo podkreślając atrakcyjność inwestycyjną spółek, którą charakteryzuje m.in. jakość raportowania, poziom relacji inwestorskich czy ład informacyjny. Jest to pierwszy w Europie Środkowo-Wschodniej indeks spółek odpowiedzialnych. W skład RESPECT Index, w wyniku weryfikacji stopnia spełnienia przyjętych kryteriów, wchodzą każdorazowo wyłącznie spółki giełdowe działające zgodnie z najlepszymi standardami zarządzania również w obszarach czynników ekologicznych, społecznych i pracowniczych. Od pierwszej publikacji 19 listopada 2009 roku do grudnia 2015 roku RESPECT Index zyskał 31\%, natomiast WIG wzrósł o 11\%[http://www. odpowiedzialni.gpw.pl, 2016].

Polski indeks RESPECT zdecydowanie jest coraz bardziej popularny. Potwierdza to także badanie przeprowadzone przez GPW oraz firmę Deloitte, którego celem było zdefiniowanie poziomu świadomości polskich inwestorów nt. CSR oraz szans rozwojowych związanych z uwzględnianiem czynników środowiskowych, społecznych i ładu korporacyjnego w procesie podejmowania decyzji inwestycyjnych. Ponad $82 \%$ biorących udział w badaniu jest świadoma funkcjonowania na GPW indeksu spółek odpowiedzialnych. Pomimo odnotowania generalnie wysokiego poziomu świadomości odnośnie faktu funkcjonowania Indeksu RESPECT, aż 70\% inwestorów nie jest w stanie wskazać, jakie spółki wchodzą w jego skład. Ponadto, mimo że większość badanych dostrzega bezpośredni wpływ działań CSR na wyniki finansowe przedsiębiorstw, ponad 50\% nie dostrzega bezpośredniego przełożenia aktywności w zakresie CSR na obniżenie ryzyka biznesowego w przypadku spółek działających na rynku polskim. Jednakże, jednym z istotniejszych wniosków z badania jest stwierdzenie, iż należy spodziewać się, że odbiór CSR jako instrumentu służącego aktywnemu obniżaniu ryzyka biznesowego w przedsiębiorstwach będzie wśród inwestorów zyskiwać na znaczeniu wraz ze wzrostem liczby firm, które wdrażają strategie CSR jako element ich strategii biznesowej [Decyzje inwestycyjne a społeczna odpowiedzialność firm. Raport z badania, 2011]. 
Tabela 1 Wykaz spółek wchodzących w skład RESPECT Index - grudzień 2015r.

\begin{tabular}{|l|l|}
\hline Apator S.A. & ING Bank Śląski S.A. \\
\hline Bank BPH S.A. & KGHM Polska Miedź S.A. \\
\hline Bank Handlowy w Warszawie S.A. & Lubelski Węgiel Bogdanka S.A. \\
\hline Bank Millennium S.A. & Orange Polska S.A. \\
\hline Bank Ochrony Środowiska - nowa spółka & Pelion S.A. \\
\hline Bank Zachodni WBK S.A. & PGE Polska Grupa Energetyczna S.A. \\
\hline Budimex S.A. & Polskie Górnictwo Naftowe i Gazownictwo S.A. \\
\hline Elektrobudowa S.A. & Polski Koncern Naftowy ORLEN S.A. \\
\hline Energa SA & Powszechny Zakład Ubezpieczeń S.A. \\
\hline GPW S.A. & Tauron Polska Energia S.A. \\
\hline Grupa Azoty S.A. & Zespół Elektrociepłowni Wrocławskich KOGE- \\
& NERACJA S.A \\
\hline Grupa LOTOS S.A. & \\
\hline
\end{tabular}

Źródło : http://www.odpowiedzialni.gpw.pl [10.02.2016]

RESPECT Index raz na pół roku przechodzi rewizję składu. W grudniu 2015 roku ogłoszono wyniki 9. edycji RESPECT Indeksu. Znalazły się w nim 23 firmy, w tym nowa spółka: Bank Ochrony Środowiska. GWP w Warszawie we współpracy z partnerami zewnętrznymi oceniając spółki zarządzane w sposób odpowiedzialny i zrównoważony, weryfikują się w wieloetapowy badaniu. Wyniki najnowszej edycji, wskazują na rozwijanie i ugruntowanie koncepcji społecznej odpowiedzialności biznesu wśród polskich przedsiębiorstw. Wszystkie spółki zidentyfikowało i udokumentowało swój wpływ na środowisko naturalne, w tym ponad połowa $\mathrm{z}$ nich zmierzyła swój wpływ pośredni. Blisko 100\% spółek określiło cele $\mathrm{w}$ zakresie ograniczenia lub niezwiększenia stopnia zużycia paliw i energii. Wśród czynników społecznych weryfikowanych przez komisję zdecydowanie wzrósł procent spółek badających nastroje i poziom zaangażowania swoich pracowników (2014: 78\%,2015: 86\% ). Zaskakujący jest fakt spadku spółek wprowadza kryteria środowiskowe, etyczne lub społeczne w procesie wyboru dostawcy do 46\% (w 2014: 50\%). Prawie 3/4 spółek umieszcza w podpisywanych umowach obligatoryjne, standardowe klauzule etyczne, społeczne lub środowiskowe, a 39\% spółek wprowadza i egzekwuje klauzulę dot. przeprowadzania audytu wypełniania wyżej wymienionych warunków. Istotnym z punktu widzenia komunikacji biznesowej z otoczeniem spółek jest fakt, iż 74\% spółek przygotowuje raporty w oparciu o wytyczne Global Reporting Initiative, a ponad połowa poddaje je niezależnej weryfikacji. Wzrost liczby spełniających globalne wytyczne do raportowania z obszaru odpowiedzialności społecznej też zapewne wpłynie na podniesienie stopnia postrzegania działań 
CSR jako czynnika służącego zarządzaniu ryzykiem biznesowymi i podnoszeniu atrakcyjności inwestycyjnej jednostek.

Wszystkie 23 spółki wchodzące w skład omawianego indeksu informują na swoich stronach internetowych o prowadzonych działaniach i inicjatywach związanych z społeczną odpowiedzialnością lub zrównoważonym rozwojem. Ponad $60 \%$ spółek opracowało i wdrożyło kompleksowe strategie odpowiedzialnego biznesu, ale tylko 7 podmiotów monitoruje realizację tą strategię. Dobrym wynikiem jest liczba spółek dokonujących kompleksowego przeglądu kluczowych elementów systemu kontroli wewnętrznej i zarządzania ryzykiem (20 spółek).

Koncepcja społecznej odpowiedzialności powinna stać się priorytetem dla przedsiębiorstw, dla których sukces jest najważniejszy. Z pewnością wprowadzenie indeksu tej kategorii na GPW oznacza pewien pozytywny przełom dla idei CSR w polskiej praktyce gospodarczej. Na podstawie przytoczonych wyników badań oraz sformułowanych na podstawie nich wniosków, można stwierdzić, iż polskie przedsiębiorstwa znają wiele pozytywnych przejawów z przyjęcia założeń CSR do działalności biznesowej. Wprowadzenie i ciągły rozwój indeksu RESPECT może stać się aspektem motywującym i mobilizującym pozostałe jednostki nieznające do tej pory koncepcji społecznej odpowiedzialności biznesu do zapoznania się, a w dalszej perspektywie wdrożenia tej koncepcji do strategii przedsiębiorstwa. Mimo dużego zainteresowania ze strony kadry menadżerskiej, a także instytucji otoczenia biznesu, obecnie CSR to wciąż nowy, rozwijany obszar na polskim rynku. Działania te incydentalnie prowadzone są we wszystkich obszarach, najczęściej przedsiębiorstwa wybierają jeden obszar, głównie w celu poprawy wizerunku jednostki, bez podjęcia działań długoterminowych. Natomiast przykład spółek z RESPECT Index potwierdza, iż coraz więcej zarządzających i kierowników jednostek postrzega działalność swojego przedsiębiorstwa w szerszej perspektywie, dostosowując swoje modele biznesowe do współczesnego otoczenia gospodarczego uwzględniającego środowisko i społeczność na taki samym poziomie istotności jak czynniki ekonomiczne.

\section{PODSUMOWANIE}

Koncepcja społecznej odpowiedzialności to idea i narzędzie przyczyniające się do osiągania przewagi konkurencyjnej. Zwiększenie wsparcia ze strony zarządów przedsiębiorstw dla koncepcji społecznej odpowiedzialności oraz wzmacnianie zaangażowania kadry zarządzającej na rzecz omawianej koncepcji jest obecnie wyznaniem dla popularyzacji CSR. Przedsiębiorstwa, które chcą być uważane za wiarygodne w swojej działalności, powinny poddawać się weryfikacji zewnętrznej, aby budować zaufanie wśród interesariuszy. Łatwy dostęp 
do informacji na temat działalności przedsiębiorstwa w zakresie CSR gwarantują publikowane raporty. Optymalnym rozwiązaniem byłaby również sytuacja, w której strategia firmy istnieje w formie odrębnego, spisanego dokumentu dotyczącego CSR (lub elementów CSR), zawierająca mierzalne i osadzone w czasie cele, zaplanowaną drogę ich osiągnięcia.

Reasumując, można powiedzieć, iż wdrażanie programów CSR staje się istotnym elementem zarządzania. Minie kilka lat zanim wszystkie przedsiębiorstwa staną się świadome wagi kwestii społecznych i będą umiały spójnie wyznaczyć działania biznesowe i społeczne oraz zbudują programy CSR i wkomponują je w pełni strategię.

\section{LITERATURA}

Gierusz B., Martyniuk T., (2009) Rola rachunkowości w świetle społecznej odpowiedzialności przedsiębiorstwa (CSR), [w:] Problemy wspótczesnej rachunkowości, Pracownicy Katedry Rachunkowości SGH (red.), SGH, Warszawa.

Griffin R.W., (2004), Podstawy zarzadzania organizacjami, Wydawnictwo Naukowe PWN, Warszwa

Grudzewski W. M., Hejduk I. K., Sankowska A., Wańtuchowicz M.,(2010) Sustainability w biznesie, czyli przedsiębiorstwo przyszłości, zmiany paradygmatów i koncepcji zarządzania, Poltext, Warszawa.

Roszkowska P., (2011), Rewolucja w raportowaniu biznesowym. Interesariusze, konkurencyjność, społeczna odpowiedzialność, Difin, Warszawa.

Sachs, J., (2009), Nasze wspólne bogactwo. Ekonomia dla przeludnionej planety., Wydawnictwo Naukowe PWN, Warszawa.

Śnieżek E., Wiatr M.,(2014), Zintegrowane raportowanie biznesowe przedsiębiorstwa społecznie odpowiedzialnego $w$ dobie zrównoważonego rozwoju, Studia Prawno-Ekonomiczne (XCI/2), Łódzkie Wydawnictwo Naukowe, Łódź.

Wróblewska K., (2015), RESPECT Index jako bodziec do społecznie odpowiedzialnego inwestowania w Polsce, Prace Naukowe Uniwersytetu Ekonomicznego we Wrocławiu, nr 378.

Zuzek D.,(2012), Społeczna odpowiedzialność biznesu a zrównoważony rozwój przedsiębiorstw, Zeszyty Naukowe Małopolskiej Wyższej Szkoły Ekonomicznej w Tarnowie, T.21, nr 2.

Żychlewicz M., (2015), Społeczna odpowiedzialność biznesu jako strategia prowadzenia działalności polskich przedsiębiorstw, Współczesne Problemy Ekonomiczne nr 11, Zeszyty Naukowe nr 858, Szczecin.

http://www.odpowiedzialni.gpw.pl [10.02.2016]

Decyzje inwestycyjne a społeczna odpowiedzialność firm. Raport z badania, (2011),[online] http://www.odpowiedzialni.gpw.pl/pub/files/RAPORT-Decyzje_inwestycyjne_a_CSR. pdf. [20.02.2016]

Ocena stanu wdrażania standardów społecznej odpowiedzialności biznesu wraz z opracowaniem zestawu wskaźników społecznej odpowiedzialności w mikro, małych, średnich i dużych przedsiębiorstwach, 2012[online] https://badania.parp.gov.pl/files/74/75/77/13078.pdf. [22.02.2016]

CSR jako podstawa budowy wartości firmy [online], Makuch Ł., http://www.paiz.gov.pl/files/?id_ plik=18231. [20.02.2016]

Sustainability nears a tipping point, D. Kiron, N. Kruschwitz, K. Haanaes, I. von Streng Velken, 
MIT Sloan Management Review, Winter 2012, VOL.53 NO.2 [online] http://archive.epa. gov/sustainablemanufacturing/web/pdf/mit-smr-bcg-sustainability-nears-a-tipping-pointwinter-2012.pdf [15.02.2016]

http://csr.forbes.pl/liderzy-zrownowazonego-rozwoju-wyniki-iv-edycji-konkursu-forbesa-i-pwc,artykuly,182156,1,1.html [20.02.2016]

\title{
STRATEGY OF SOCIALLY RESPONSIBLE COMPANY ON THE EXAMPLE OF POLISH LISTED COMPANIES
}

\begin{abstract}
The purpose of this article is to present the practice of Polish companies listed on the Warsaw Stock Exchange in terms of achieving the objectives of the concept of corporate social responsibility. To realize this objective article is divided into three parts, the first presents the assumptions of the concept of social responsibility, while the second discusses the impact of this concept on the construction and implementation of strategies in modern units. It then discusses the current state of implementation of CSR in strategic activities of Polish listed companies, mainly referring to the companies included in the RESPECT Index. The article was used to study literature, analysis of secondary documents
\end{abstract}

Keywords: corporate strategy, corporate social responsibility, Respect Index 